\title{
Impact of pollutant emission from motor vehicles on air quality in a city agglomeration
}

In the large urban areas, in middle latitudes, as in case of Poland, the cause of poor air quality is immission: in winter particulate matter PM10 and PM2.5, in summer - ozone and nitrogen oxides (or nitrogen dioxide). In the whole country, road transport is significantly responsible for the emission of nitrogen oxides (30\%), carbon monoxide (20\%) and less for emission of particulate matter (a few percent). In the case of other pollutants, the emission of non-metallic organic compounds is less than 10\% (including polycyclic organic compounds - just over $0.5 \%$ ), and sulfur oxides - only $0.03 \%$ !

To analyze impact of automotive industry on air quality, pollutant emission data from two stations in Krakow were selected. These stations are known for poor air quality - the stations are: Dietla Street - with a high level of traffic and Kurdwanów - place located far from traffic routes. It was found that other objects than automotive vehicles are the dominant source of dust. These are industrial sources and - above all - energy sources, especially individual heating installations. Particularly large dust pollution occurs in winter and it is not always in areas with intense traffic. There was a strong dependence between immission of pollutants and road traffic, however, this dependence is not dominant in assessing the risk of air quality in urban agglomerations.

Key words: emission of pollutants, immission of pollutants, motor vehicles

\section{Introduction}

There is social acceptance, especially in liberal consumer societies, for determining the dominant influence of automotive on air pollution, especially in urban agglomerations. Such views are common even in scientific environments, and in the opinion-forming circles they even adopt hysterical instead of factual character. Undoubtedly, the impact of automotive pollution is important for the air quality, especially on a local scale and at a time when traffic is very intense [1-8]. It is known that usually other sources are dominant, and not only related to anthropogenic sources of pollutant emission, but also to natural phenomena [7, 9]. These natural phenomena include commonly known risks associated with winds from great deserts. Anthropogenic sources of pollutant emission, especially dangerous for air quality, are primarily energy, and especially distributed energy associated with local heating of buildings. This condition is confirmed by numerous research results of air quality [3-5].

The air quality is controlled in many measuring stations - which is in line with international agreements. In Poland, to assess the air quality, the Polish Air Quality Index has been introduced by the Chief Inspectorate of Environmental Protection.

Table 1 presents limit values of immission ${ }^{1}$ of pollutants for the Polish Air Quality Index for individual substances.

Immission of pollutants is determined at air quality monitoring stations by automatic measurement method and averaged over $1 \mathrm{~h}$.

Polish Air Quality Index (pl. Polski Indeks Jakości Powietrza, PIJP) is a detailed index determined for pollution, which is dominating during the averaging of measurements in the area of the province.

\footnotetext{
${ }^{1}$ Immission is the concentration of pollutants dispersed in the atmosphere, measured at $1.5 \mathrm{~m}$ above the ground.
}

$$
\mathrm{PIJP}=\operatorname{Max}\left[\mathrm{PIJP}_{\mathrm{s}}\right]
$$

where: Max - operator of the maximum value.

Tab. 1. Limit values of pollution immission for the Polish Air Quality Index for specific substances - PIPSs

\begin{tabular}{|l|c|c|c|c|c|c|c|c|}
\hline & & PM10 & PM2.5 & O $_{3}$ & NO $_{2}$ & SO $_{2}$ & $\mathrm{C}_{6} \mathrm{H}_{6}$ & CO \\
\hline & & \multicolumn{7}{|c|}{$\left[\mu \mathrm{g} / \mathrm{m}^{3}\right]$} \\
\hline Very good & 1 & 20 & 12 & 70 & 40 & 50 & 5 & 2 \\
\hline Good & 2 & 60 & 36 & 120 & 100 & 100 & 10 & 6 \\
\hline Moderate & 3 & 100 & 60 & 150 & 150 & 200 & 15 & 10 \\
\hline Sufficient & 4 & 140 & 84 & 180 & 200 & 350 & 20 & 14 \\
\hline Bad & 5 & 200 & 120 & 240 & 400 & 500 & 50 & 20 \\
\hline Very bad & 6 & $>200$ & $>120$ & $>240$ & $>400$ & $>500$ & $>50$ & $>20$ \\
\hline No index & & - & - & - & - & - & - & - \\
\hline
\end{tabular}

Practice indicates that the dominant pollutants due to air quality are: in the winter, the immission of particle size fractions PM10 and PM2.5 and in the summer the nitrogen dioxide and ozone emission.

For the summer, poor air quality can be bound to automotive pollution, although this is not the only pollution source. In the winter, however, the heating sector has the dominating influence on air quality.

In general, the impact of road transport on the air quality is not as dominant as it is believed, even among some scientists. Table 2 presents the contribution of national annual emission of pollutants from the road transport sector in the total national annual emission of pollutants from all civilization sources in Poland in 2017 [10]. 
Tab. 2. Share of the annual emission of pollutants from the road transport sector in the total national annual emission of pollutants from all civilization sources in Poland in 2017

\begin{tabular}{|l|c|}
\hline Pollutant & Share [\%] \\
\hline CO & 20.7 \\
\hline NMVOC & 8.9 \\
\hline PAH & 0.6 \\
\hline NOx & 29.9 \\
\hline TSP & 4.5 \\
\hline PM10 & 5.3 \\
\hline PM2.5 & 7.8 \\
\hline SOx & 0.03 \\
\hline
\end{tabular}

As it is shown, a large share of automotive emission are nitrogen oxides (about 30\%), which contribute to the threat of photochemical smog in the summer and carbon monoxide (about 20\%). The share of dust emission is a few percent - in the case of particulate matter PM10, the dominant pollution in winter, the share is about $5 \%$. The participation of polycyclic aromatic hydrocarbons $(0.6 \%)$, and especially of sulfur oxides $(0.03 \%$ !) is completely trace.

Since Krakow is commonly used as an example of the environmental threat posed by the automotive industry, it was decided to analyze the results of measurements carried out at two stations of air quality monitoring: at Dietla Street which is located in the area of heavy traffic of motor vehicles and in Kurdwanów - in the area deprived of the dominating share of automotive industry in air pollution.

\section{Results of empirical measurements}

The pollutant emission data was provided by the air quality monitoring stations. This data is publicly available (for instance on relevant websites) in accordance with applicable law.

Figure 1 shows the immission of particulate matter PM10 values obtained from Kraków-Dietla station and Kraków-Kurdwanów station in 2016.

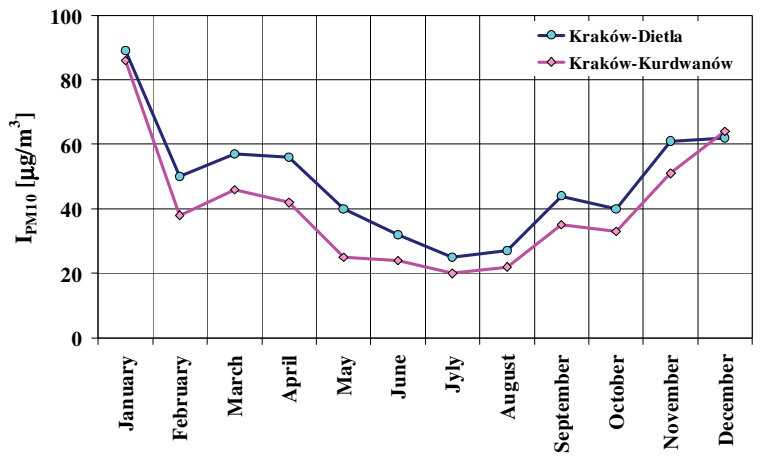

Fig. 1. The immission of particulate matter PM10 values obtained from Kraków-Dietla station and Kraków-Kurdwanów station in 2016

It is clearly visible that, in the so-called 'heating period', the immission of particulate matter PM10 is significantly higher comparing to summer months. The particulate matter immission PM10 values obtained from KrakówDietla station are stably higher, although the difference is not significant and does not indicate dominant influence of automotive industry.

Figure 2 shows the immission of particulate matter PM10 on 6 January 2016.

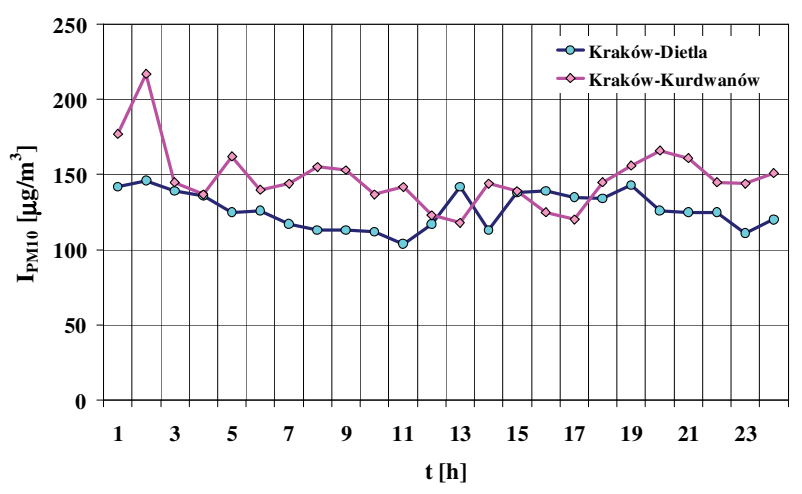

Fig. 2. The immission of particulate matter PM10 on 6 January 2016

In most part of the day the immission of particulate matter PM10 is significantly higher on Kraków-Kurdwanów station - impact of automotive industry on the immission of particulate matter is not striking even at rush hours.

Figure 3 shows the immission of particulate matter PM10 on 8 June 2016.

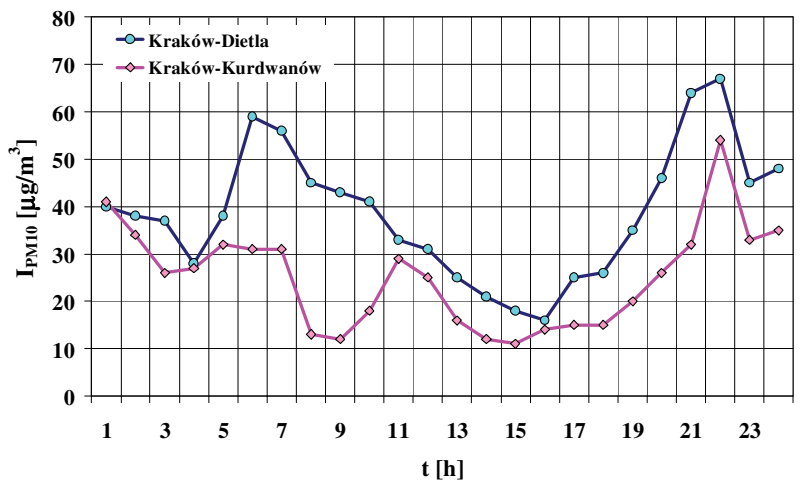

Fig. 3. The immission of particulate matter PM10 on 8 June 2016

The mean value of the immission of particulate matter PM10 in this particular case is considerably higher at the Kraków-Dietla station. This indicates that the automotive industry has a major impact on air pollution. However, these values of the immission are four times lower than in winter season.

The impact of the dust emission from municipal sources is particularly visible in Figs 4 and 5.

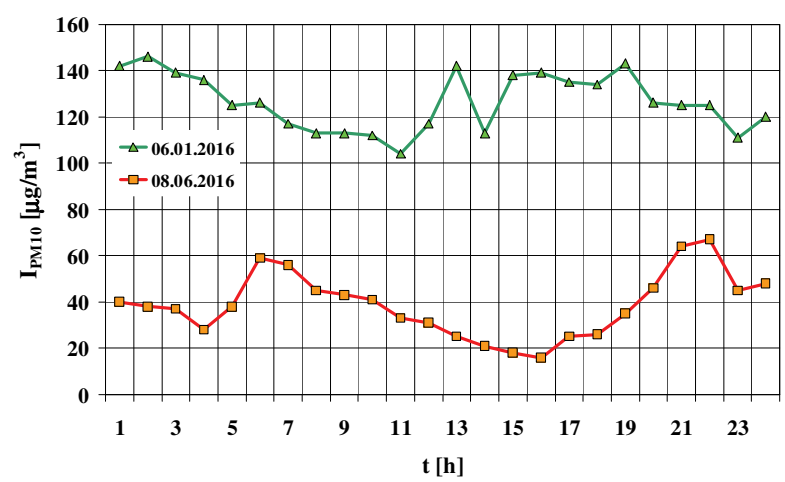

Fig. 4. The immission of particulate matter PM10 values obtained from Kraków-Dietla station on 6 January 2016 and 8 June 2016 


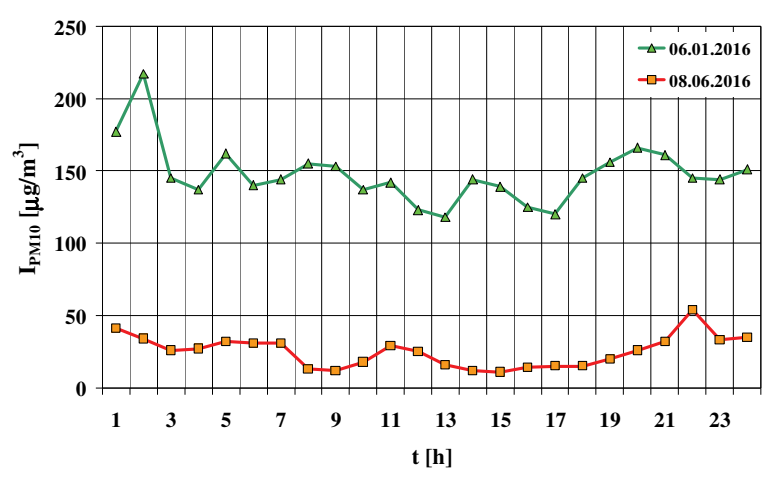

Fig. 5. The immission of particulate matter PM10 values obtained from Kraków-Kurdwanów station on 6 January 2016 and 8 June 2016

The similar comparison was made for the immission of nitrogen dioxide, a dominant pollutant in summer months.

Figure 6 shows the immission of the nitrogen dioxide in 2016 obtained from Kraków-Dietla station and KrakówKurdwanów station.

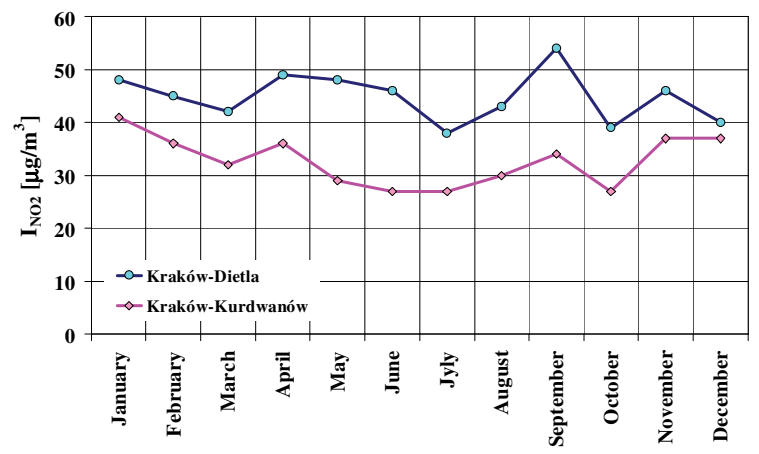

Fig. 6. The immission of nitrogen dioxide values obtained from KrakówDietla station and Kraków-Kurdwanów station in 2016

Figure 6 shows the impact of automotive indutsry on nitrogen dioxide immission at Kraków-Dietla station.

Figures 7 and 8 shows immission of nitrogen dioxide on 6 January 2016 and 8 June 2016.

Figures 7 and 8 show the impact of automotive industry on nitrogen dioxide immission - higher values were observed at Dietla station at rush hours.



Fig. 7. The immission of nitrogen dioxide on 6 January 2016

Figures 9 and 10 show a comparison of nitrogen dioxide immission. The data was collected by both stations in winter and summer time respectively.

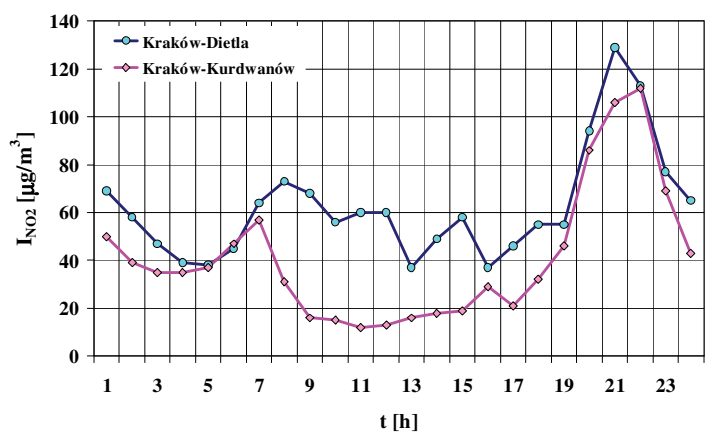

Fig. 8. The immission of nitrogen dioxide on 8 June 2016

As it is shown in Figures 9 and 10, automotive industry is a major source of nitrogen dioxide emission, especially in summer.

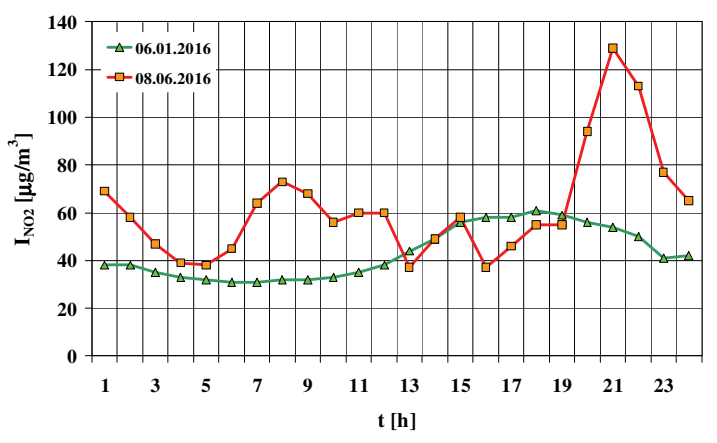

Fig. 9. The immission of nitrogen dioxide values obtained from KrakówDietla station on 6 January 2016 and 8 June 2016

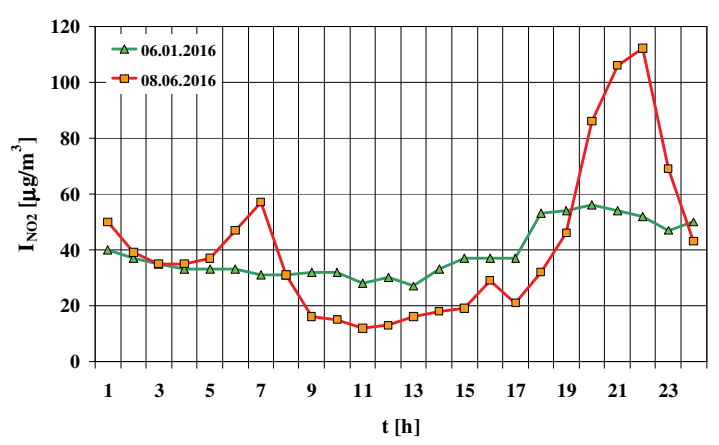

Fig. 10. The immission of nitrogen dioxide values obtained from KrakówKurdwanów station on 6 January 2016 and 8 June 2016

It is similar to nitrogen oxides immission - Figs 11-15.

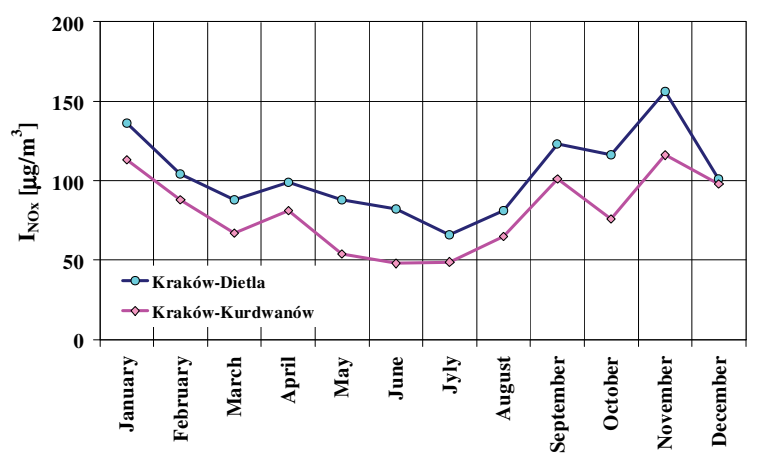

Fig. 11. The immission of nitrogen oxides values obtained from KrakówDietla station and Kraków-Kurdwanów station in 2016 


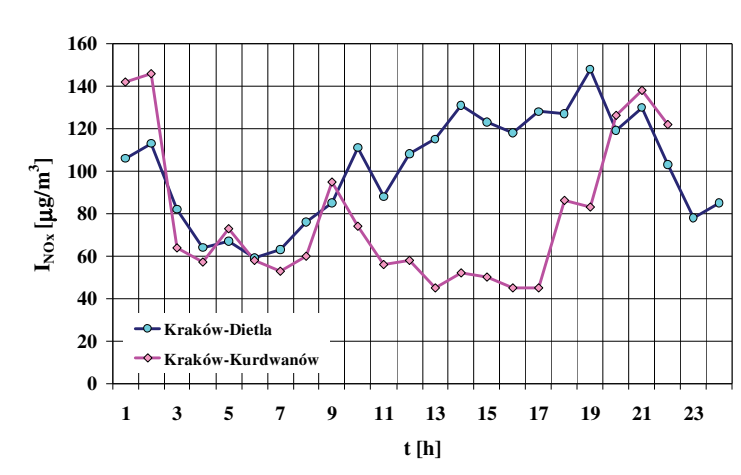

Fig. 12. The immission of nitrogen oxides on 6 January 2016

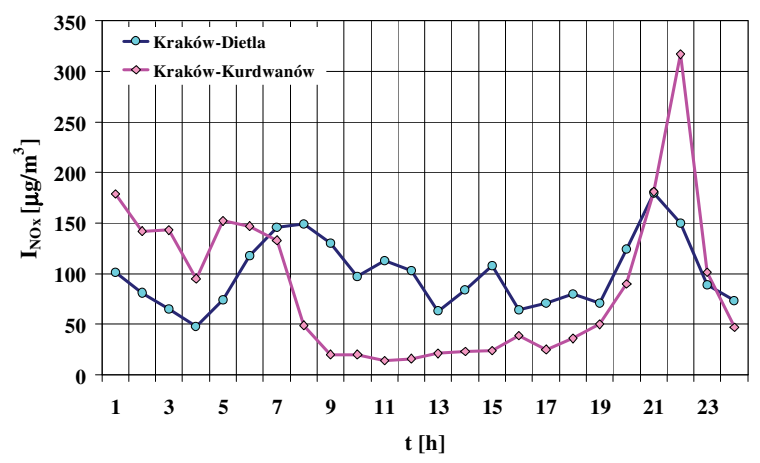

Fig. 13. The immission of nitrogen oxides on 8 June 2016

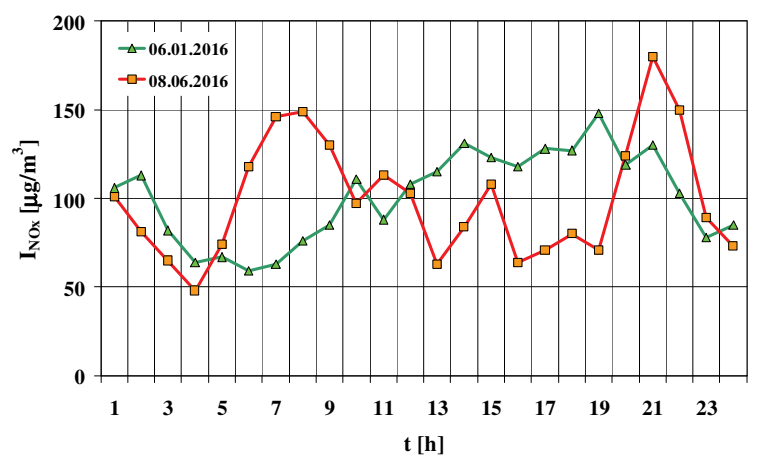

Fig. 14. The immission of nitrogen oxides values obtained from KrakówDietla station on 6 January 2016 and 8 June 2016

The results from the research confirm moderate impact of motor vehicles on air quality in a city agglomeration. Other revelations from a number of quality scientific journals confirm such assessment [1-8]. Of course, automotive industry threats are not to be underestimated but only rational actions supported by objective evaluation of the situation should be taken. Propagandistic and unprofessional actions such as mass checking of exhaust components concentration in spark-ignition engines at idling speed in winter time when there are large exceedances of dust immission not only do not bring any benefits but are also quite harmful as social resources are unnecessarily wasted.

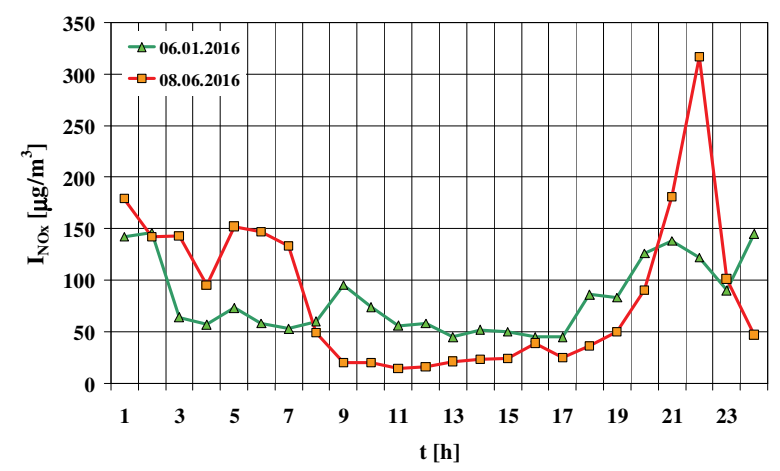

Fig. 15. The immission of nitrogen oxides values obtained from KrakówKurdwanów on 6 January 2016 and 8 June 2016

\section{Recapitulation}

By summarizing the above data, it possible to draw the following conclusions:

1. The cause of poor air quality is immission: in winter particulate matter PM10 and PM2.5, in summer - ozone and nitrogen oxides.

2. Road transport is significantly responsible for the emission of nitrogen oxides $(30 \%)$, carbon monoxide $(20 \%)$ and less for emission of particulate matter (a few percent).

3. The dominant sources of dust are other objects different than automotive vehicles. These are industrial sources and - above all - energy sources, especially individual heating installations. Particularly large dust pollution occurs in winter and it is not always in areas with intense traffic.

4. The research from a number of other air quality monitoring stations confirms the conclusions drawn in this paper.

\section{Nomenclature}

I

$\mathrm{CO} \quad$ carbon monoxide

NMVOC non-methane volatile organic compounds

$\mathrm{NO}_{2} \quad$ nitrogen dioxide

$\mathrm{NO}_{\mathrm{x}} \quad$ nitrogen oxides
PM10 particular matter PM10

PM2.5 particular matter PM2.5

$\mathrm{SO}_{\mathrm{x}} \quad$ sulphur oxides

TSP total suspended particles

PAH polycyclic aromatic hydrocarbons

\section{Bibliography}

[1] CANAGARATNA, M. Chase studies of particulate emissions from in-use New York City vehicles. Aerosol Science and Technology. 2004, 38(6), 555-573.
[2] CHŁOPEK, Z., ŻEGOTA, M. The emission of particulate matter PM10 from vehicles. Eksploatacja i Niezawodność Maintenance and Reliability. 2004, 21(1), 3-13. 
[3] CHŁOPEK, Z. Testing of hazards to the environment caused by particulate matter during use of vehicles. Eksploatacja i Niezawodnosc - Maintenance and Reliability. 2012, 14(2), 160-170.

[4] CHŁOPEK, Z., SUCHOCKA, K. Risk posed by particulate master to the human and environment near transport router. The Archives of Automotive Engineering - Archiwum Motoryzacji. 2014, 63(1), 3-22.

[5] CHŁOPEK, Z. Examination of a particulate matter PM10 immission model in the environment around road transport routes. The Archives of Automotive Engineering - Archiwum Motoryzacji. 2012, 55(1), 23-38.

[6] XIE, X. et al. A review of urban air pollution monitoring and exposure assessment methods. SPRS International Journal of Geo-Information, 2017, 6(389). DOI:10.3390/ ijgi6120389.

Prof. Zdzisław Chłopek, DSc., DEng. - Automotive and Construction Machinery Engineering, Warsaw University of Technology.

e-mail: zdzislaw.chlopek@pw.edu.pl

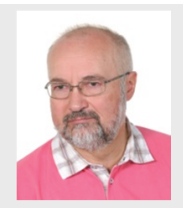

Jakub Lasocki, DEng. - Faculty of Automotive and

Construction Machinery Engineering, Warsaw

University of Technology.

e-mail: jakub.lasocki@pw.edu.pl
[7] OBANYA, H.E. et al. Air pollution monitoring around residential and transportation sector locations in Lagos Mainland. Journal of Health and Pollution. 2018, 8(19), 180903.

[8] KRZYZANOWSKI, M. et al. Air pollution in the megacities. Current Environmental Health Reports. 2014, 1(3), 185-191.

[9] HOUTHUJIS, D. et al. PM10 and PM2.5 concentrations in central and eastern Europe: Results from the CESAR study. Atmospheric Environment. 2001, 35, 2757-2771.

[10] Poland's Informative Inventory Report 2018. Submission under the UN ECE Convention on Long-range Transboundary Air Pollution and the Directive (EU) 2016/2284 Warszawa, National Centre for Emission Management (KOBiZE) at the Institute of Environmental Protection - National Research Institute. February 2018.

Katarzyna Strzałkowska, MEng. - Grupa TOPEX.

e-mail: k.strzalkowska@grupatopex.com

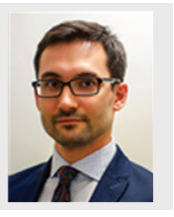

Dagna Zakrzewska, MEng. - Analitycal Laboratory,

Automotive Industry Institute.

e-mail: d.zakrzewska@pimot.eu 